\title{
Serum Bilirubin Levels Can be Used as a Potential Biomarker in the Progression of Diabetic Nephropathy in Rats
}

\author{
SOHAIR A. SALEH, M.D.*; ASMAA G. ABDOU, M.D.**; ESRAA A. SALEM, M.Sc.* and \\ SUZAN M. HAZZAA, M.D.* \\ The Departments of Physiology* and Pathology**, Faculty of Medicine, Menoufia University, Egypt
}

\begin{abstract}
Background: Diabetes mellitus is a widespread syndrome and a major cause of morbidity and mortality all over the world. Diabetic nephropathy is a progressive and irreversible renal affection that may end by renal failure in sever conditions. Bilirubin is the end product of heme catabolism. It has been recognized as a strong antioxidant. Many studies relate bilirubin to diabetes.
\end{abstract}

Aim of Study: The present investigation aimed to study the changes in serum billirubin level in diabetic nephropathy and to know whether there is a correlation between its level and the stages of nephropathy in diabetic rats.

Material and Methods: Sixty male albino rats were used and divided into the following groups; non-diabetic contro group, diabetic nephropathy group and insulin-treated diabetic nephropathy group. By the end of the experimental period, 24 hours urine samples were collected to measure urine volume $\&$ urinary creatinine concentration and calculation of creatinine clearance. Then systolic blood pressure (SBP) was measured using rat tail sphygmomanometer technique. Fasting blood samples were collected for estimation of glycemic state, liver function tests and renal function tests. Finally both kidneys were fixed in $10 \%$ formalin solution for histopathology by using H\&E \& periodic acid schiffe (PAS).

Results: Our data showed that streptozotocin injection significantly elevated glycemic state, aspartate transaminase (AST), alanine transaminase (ALT), serum urea, serum creatinin, SBP and significantly decreased seum albumin, creatinin clearance, total and direct bilirubin. Alkaline phosphatase (ALP) and serum albumin showed insignificant change. Histopathological examination of the same group showed slight thickening of the basement membrane, arterioles, few inflammatory cells and hydropic changes in renal tubules. Insulin treatment significantly decreased glycemic state, AST, ALT, serum urea, serum creatinin, SBP and significantly elevated seum albumin, creatinin clearance, total and direct bilirubin. Histopathological examination of the same group showed some healthy glomeruli but still hydropic changes in renal tubules.

Conclusion: Regular monitoring of bilirubin in diabetic patients is essential marker for progression and prognosis of diabetic nephropathy and effect of treatment.

Key Words: Diabetes - Nephropathy - Bilirubin.

Correspondence to: Dr. Sohair A. Saleh,

The Department of Physiology, Faculty of Medicine,

Menoufia University, Egypt

\section{Introduction}

DIABETES mellitus (DM) is a group of metabolic disorders characterized by hyperglycemia which results from decrease in insulin secretion, insulin action or both [1]. Hyperglycemia is the prominent feature of diabetes; it activates certain biochemical pathways leading to micro and macrovascular complications [2]. Also, it generates free radicals causing oxidative stress and mediates lipid peroxidation [3]. This oxidative stress causes endothelial dysfunction, and has been suggested as one of the important mechanisms underlying the onset and progression of diabetic vascular complications [4] Diabetic nephropathy is a major long-term complication in diabetes mellitus. It is characterized by increased blood pressure, reduced renal function and presented by microalbuminuria with progression to overt proteinuria [5] . Bilirubin, the end product of heme catabolism, is known to exhibit strong anti-oxidant and anti-inflammatory properties on the vasculature [6]. Also, many clinical studies reported inverse relation between serum bilirubin level and many diseases like diabetes [7]. Serum bilirubin concentration inversely correlated with the marker of oxidative stress and positively correlated with antioxidant enzymes such as superoxide dismutase, catalase, and glutathione peroxidase [8]

\section{Aim of the work:}

The present investigation aimed to study the changes in serum billirubin level in diabetic nephropathy and to know whether there is a correlation between its level and the stages of nephropathy in diabetic rats.

\section{Material and Methods}

Animal design and induction of diabetes:

Sixty adult male albino rats of local strains, weighing 150-200 grams each, were used in this investigation. This work was held from September 
2015 to March 2016. Rats were caged (5/cage) in fully ventilated cages and housed in animal house of faculty of Medicine Menoufia university under artificial light/dark cycle of $12 \mathrm{~h}$ with free access to water and semi-synthetic balanced diet.

Rats were divided into the following groups: Group I: Non-diabetic control group (10 rats); these rats were injected intraperitonealy by citrate buffer only, Group II: Diabetic group; Diabetes was induced by a single intraperitoneal injection of STZ (Sigma Chemical Company, USA) $(60 \mathrm{mg} /$ $\mathrm{Kg}$ ) in $0.2 \mathrm{ml}$ of $10 \mathrm{mmol} / 1$ citrate buffer $(\mathrm{pH} 5.5)$ after overnight fasting [9]. $0.5 \mathrm{ml}$ dextrose $5 \%$ was given intraperitoneally 30 minutes before STZ injection as a protective dose and rats were supplied with sucrose in the drinking water $(10 \%)$ to avoid sudden hypoglycemia after injection [10]. Rats were confirmed to be diabetic when fasting blood glucose levels exceeded $250 \mathrm{mg} / \mathrm{dL} 48$ hours after STZ injection [11]. Then diabetic rats were followed up by estimation of urinary albumin level and divided according to urinary albumin into the following subgroups (10 rats each): Group IIa: Early diabetic with no or minimal albumin in urine, Group IIb: (Microalbuminuric diabetic nephropathy group (microalb.-DN); diabetic with microalbuminuria (when urine albumin $>30 \mathrm{mg} /$ day), Group IIc: (Macroalbuminuric diabetic nephropathy group (macroalb.-DN); diabetic with macroalbuminuria (when urine albumin $>300 \mathrm{mg} /$ day) [12]. Group III: Insulintreated diabetic group; diabetes was induced as mentioned above then, it was divided into the following subgroups (10 rats each): Group IIIa; insulin-treated microalbuminuric diabetic nephropathy group and Group IIIb: Insulin-treated macroalbuminuric diabetic nephropathy group. In these groups rats were treated by subcutaneous injection of insulin $(0.75 \mathrm{IU} / 100 \mathrm{gm} \mathrm{B.W}$.) once daily for 4 weeks [10]. At the end of the experiment the SBP was measured using rat tail sphygmomanometer technique [13]. Rats were fasted for 12 hours then retrorbital blood samples were collected using a fine heparinized capillary tube introduced into the medial epicanthus of the rat's eye [14]. Three millimeters of blood were collected in a clean graduated centrifuge tube. 1 millimeter is transferred into EDTA tube for quantitative colorimetric (Double beam spectro-photometer U.V. 150, Germany) determination of glycated hemoglobin (Teco diagnostics kits, USA) [15]. The other 2 millimeters left for clotting at room temperature in water bath for 15 minutes, and then centrifuged (Narco- Biosystem, U.K.) at 3000 r.p.m (rotation per minute) for 15 minutes. The supernatant serum was collected in dry tubes for estimation of: Fasting blood glucose, liver function tests ALT, AST, ALP, serum albumin, direct billirubin, total bilirubin, renal function tests (serum creatinine and serum urea).

Finally, each rat was anaesthetized with intraperitoneal injection of urethane $(25 \%)$ in a dose of $(0.6 \mathrm{ml} / 100 \mathrm{gm})$ then the animal was laid on its back and mid line laparotomy was made to take specimens from kidney.

\section{Measurement of systolic blood pressure:}

At the end of the experimental protocol period, SPB was measured using rat-tail-cuff plethysmography (Harvard Apparatus Ltd., England) with pneumatic pulse transducer (Harvard U.K.) in conscious rats (Fujita et al., 1995). Rats should be placed for 15:30 minutes before taking the reading (XBP1000; Kent Scientific). Rats were trained for 5 consecutive days (each cession consisting of 10 unrecorded measurements) to familiarize the animal with rat tail cuff [16]

\section{Biochemical analysis:}

Blood glucose and glycosylated Hb: Glucose is determined by glucose oxidase method according to manufacturer instructions and $\mathrm{HbA} 1 \mathrm{C}$ by Kits for estimation of HbA1C (Bio diagnostic Company, Egypt).

Liver functions: Serum samples were used for estimation of AST, ALT, ALP [17] serum albumin [18], bilirubin and total bilirubin with provided kits (BIO-TEC Company, Egypt).

Renal functions: At the end of the experiment, rats were housed individually in metabolic cages for 24 hours urine collection. Urine samples were used for estimation of albumin level by specific kits (ELISA kits, DRG International, Inc,Germany) [19].

Urinary albumin level was estimated for grouping microalbuminuric and macroalbuminuric groups.

Serum urea and creatinine were measured by specific kits (Bio diagnostic Company, Egypt) according to the provided instructions [20].

Creatinine clearance was measured by the following formula [21]:

Creatinin clearance $=U$ (creatinin conc. In urine $\mathrm{mg} / \mathrm{ml}$ ) XV (volume of urine/minute $\mathrm{ml} /$ minute)/P (creatinin concentration in plasma $\mathrm{mg} / \mathrm{ml})$.

\section{Histopathology:}

Specimen from both kidneys were taken and sent to the Pathology Department, Faculty of Med- 
icine Menoufiya University, where they were submitted to routine tissue processing including fixation in $10 \%$ neutral buffered formalin. The specimen were dehydrated in graded ethanol solutions then cleared in xylene fore 20-30 minutes according to its size. The specimens were impregnated in soft paraffin wax at 55-60 $\mathrm{C}^{\circ} .4$ micron thick sections were cut from paraffin embedded blocks to be stained by haematoxylin \& eosin and Periodic Acid Schiff (PAS) stains for histopathological examination [22]

\section{Statistical analysis:}

The data were tabulated and analyzed by SPSS (statistical package for the social science software) using version 11 on IBM compatible computer. Quantitative data were expressed as mean \pm standard error of mean (X \pm S.E.M). The data from control and test groups were compared using one way analysis of variance (1-ANOVA). Probability value of less than 0.05 was considered as statistically significant $(* p<0.05)$. " $n$ " indicates the number of tested rats.

\section{Results}

\section{Biochemical analysis:}

Table (1) shows the mean value of the fasting serum glucose level in diabetic group. It was significantly higher than corresponding value in nondiabetic control group $(225.91 \pm 18.14$ vs $91.63 \pm 3.04$ $\mathrm{mg} / \mathrm{dl}$ respectively). The mean values of fasting serum glucose in microalb-DN and macroalb-DN groups were $(268.34 \pm 41.73 \& 361.44 \pm 42.98 \mathrm{mg} / \mathrm{dl}$ respectively), which were significantly higher when compared to corresponding value in diabetic group $(225.91 \pm 18.14 \mathrm{mg} / \mathrm{dl})$. The mean values of fasting serum glucose in microalb-DN and macroalb-DN insulin-treated groups were $(170.26 \pm 12.85 \&$ $190.30 \pm 14.84 \mathrm{mg} / \mathrm{dl}$ respectively) which were significantly lower when compared to the corresponding values in diabetic and diabetic nephropathy groups.

Also, the table shows that the mean value of $\mathrm{HbA1c}$ in the diabetic group, was significantly higher than corresponding value in non-diabetic control group $(6.48 \pm 0.34 \%$ vs $2.87 \pm 0.36 \%$ respectively). In microalb-DN and macroalb-DN groups it were $(7.14 \pm 0.33 \%$ \& $9.55 \pm 0.75 \%$ respectively) which were significantly higher when compared to the corresponding value in diabetic group $(6.48 \pm 0.34 \%)$. In microalb-DN and macroalb-DN insulin-treated groups it were $(3.06 \pm 0.21 \%$ \& $4.67 \pm 0.33 \%$ respectively) which were significantly lower when compared to corresponding values in diabetic and DN groups.

Regarding liver functions the same table shows that, serum ALT and AST in the diabetic group were significantly higher than corresponding values in non-diabetic control group $(29.75 \pm 3.46$ and $27.75 \pm 1.92$ vs $13.50 \pm 0.94$ and $12.50 \pm 0.76 \mathrm{U} / \mathrm{L}$ respectively). The mean values of serum ALT and AST in microalb-DN group was $(30.13 \pm 1.95 \&$ $33.13 \pm 1.36 \mathrm{U} / \mathrm{L}$ respectively) which were significantly higher when compared to the corresponding values in diabetic group $(29.75 \pm 3.46 \& 27.75 \pm$ $1.92 \mathrm{U} / \mathrm{L}$ respectively). The mean values of serum ALT and AST in macroalb-DN group were (37.38 \pm $1.91 \& 37.63 \pm 2.80 \mathrm{U} / \mathrm{L}$ respectively) which were significantly lower when compared to the corresponding values in diabetic group.

The mean values of serum ALT and AST in microalb-DN insulin treated group were $(21.25 \pm$ $1.49 \& 18.50 \pm 1.34 \mathrm{U} / \mathrm{L}$ respectively) which were significantly lower when compared to the corresponding values in diabetic group. The mean values of serum ALT and AST in macroalb-DN insulintreated group were $(26.13 \pm 1.69 \& 23.13 \pm 1.77 \mathrm{U} / \mathrm{L}$ respectively) which were significantly lower when compared to the corresponding values in diabetic and DN groups.

The mean value of ALP in diabetic group was insignificant when compared to corresponding value in non-diabetic control group $(69.75 \pm 4.20 \mathrm{U} / \mathrm{L}$ vs $52.13 \pm 3.28 \mathrm{U} / \mathrm{L}$ ). In both microalb-DN and macroalb-DN groups the mean values of ALP were $(83.37 \pm 8.49 \& 89.50 \pm 3.16 \mathrm{U} / \mathrm{L}$ respectively) which were insignificant when compared to the corresponding value in diabetic group $(69.75 \pm 4.20 \mathrm{U} / \mathrm{L})$. The mean value of ALP in both microalb-DN and macroalb-DN insulin-treated groups were $72 \pm 2.51$ $\& 81.75 \pm 6.47 \mathrm{U} / \mathrm{L}$ respectively) which were insignificant when compared to the corresponding values in diabetic and DN groups.

The mean value of serum albumin in the diabetic group was insignificant when compared to corresponding value in non-diabetic control group $(4.16 \pm 0.14$ vs $4.28 \pm 0.09 \mathrm{gm} / \mathrm{dl}$ respectively). In microalb-DN and macroalb-DN groups it were $(3.65 \pm 0.09 \& 2.07 \pm 0.26 \mathrm{gm} / \mathrm{dl}$ respectively) which were significantly lower when compared to the corresponding value in diabetic group (4.16 \pm $0.14 \mathrm{gm} / \mathrm{dl}$ ). In microalb-DN and macroalb-DN insulin-treated groups it were $(3.8 \pm 0.14 \& 3.5 \pm$ $0.22 \mathrm{gm} / \mathrm{dl}$ respectively) which were significantly higher when compared to corresponding value in DN group. 
Table (1): Fasting serum glucose \& glycosylated hemoglobin (HbA1c), Liver function tests (serum ALT, AST, ALP, albumin), Renal function tests (serum urea, serum creatinine, creatinine clearance) in all tested groups.

\begin{tabular}{|c|c|c|c|c|c|c|}
\hline & \multirow{2}{*}{$\begin{array}{l}\text { Control } \\
\text { group }\end{array}$} & \multirow{2}{*}{$\begin{array}{l}\text { Diabetic-non } \\
\text { treated }\end{array}$} & \multicolumn{2}{|c|}{$\begin{array}{l}\text { Diabetic nephropathy } \\
\text { group }\end{array}$} & \multicolumn{2}{|c|}{$\begin{array}{l}\text { Insulin-treated diabetic } \\
\text { nephropathy group }\end{array}$} \\
\hline & & & $\begin{array}{l}\text { Microalbuminuric } \\
\text { group }\end{array}$ & $\begin{array}{l}\text { Macroalbuminuric } \\
\text { group }\end{array}$ & $\begin{array}{l}\text { Microalbuminuric } \\
\text { group }\end{array}$ & $\begin{array}{l}\text { Macroalbuminuric } \\
\text { group }\end{array}$ \\
\hline $\begin{array}{l}\text { Fasting serum } \\
\text { glucose }(\mathrm{mg} / \mathrm{dl})\end{array}$ & $91.63 \pm 3.04$ & $225.91 \pm 18.14^{*}$ & $268.34 \pm 41.73 \#$ & $361.44 \pm 42.98 \#$ & $170.26 \pm 12.85 \#, \sim$ & $190.30 \pm 14.84 \#, \sim$ \\
\hline $\mathrm{HbA} 1 \mathrm{C}(\mathrm{Hb} \%)$ & $2.87 \pm 0.36$ & $6.48 \pm 0.34 *$ & $7.14 \pm 0.33 \#$ & $9.55 \pm 0.75 \#$ & $3.06 \pm 0.21 \#, \sim$ & $4.67 \pm 0.33 \#, \sim$ \\
\hline Serum ALT (U/L) & $13.50 \pm 0.94$ & $29.75 \pm 3.46^{*}$ & $30.13 \pm 1.95 \#$ & $37.38 \pm 1.91 \#$ & $21.25 \pm 1.49 \#, \sim$ & $26.13 \pm 1.69 \#, \sim$ \\
\hline Serum AST (U/L) & $12.50 \pm 0.76$ & $27.75 \pm 1.92 *$ & $33.13 \pm 1.36 \#$ & $37.63 \pm 2.80 \#$ & $18.50 \pm 1.34 \#, \sim$ & $23.13 \pm 1.77 \#, \sim$ \\
\hline Serum ALP (U/L) & $52.13 \pm 3.28$ & $69.75 \pm 4.20$ & $83.37 \pm 8.49$ & $89.50 \pm 3.16$ & $72 \pm 2.51$ & $81.75 \pm 6.47$ \\
\hline Serum albumin $(\mathrm{gm} / \mathrm{dl})$ & $4.28 \pm 0.09$ & $4.16 \pm 0.14$ & $3.65 \pm 0.09 \#$ & $2.07 \pm 0.26 \#$ & $3.8 \pm 0.14 \#, \sim$ & $3.5 \pm 0.22 \#, \sim$ \\
\hline Serum Urea (mg/dl) & $22.38 \pm 1.02$ & $25.63 \pm 1.55$ & $46.75 \pm 4.82 \#$ & $58.5 \pm 4.89 \#$ & $29.50 \pm 3.55 \#, \sim$ & $32.63 \pm 1.77 \#, \sim$ \\
\hline $\begin{array}{l}\text { Serum Creatinine } \\
(\mathrm{mg} / \mathrm{dl})\end{array}$ & $0.64 \pm 0.04$ & $0.74 \pm 0.06$ & $1.81 \pm 0.05 \#$ & $3.21 \pm 0.17 \#$ & $1.43 \pm 0.12 \#, \sim$ & $1.78 \pm 0.12 \#, \sim$ \\
\hline $\begin{array}{l}\text { Creatinine Clearance } \\
(\mathrm{ml} / \mathrm{min})\end{array}$ & $1.06 \pm 0.21$ & $0.78 \pm 0.13$ & $0.14 \pm 0.02 \#$ & $0.06 \pm 0.01 \#$ & $0.5 \pm 0.15 \#, \sim$ & $0.43 \pm 0.05 \#, \sim$ \\
\hline
\end{tabular}

Data are expressed as mean \pm S.E.M. $(\mathrm{n}=10)$.

One way ANOVA: $* p<0.05$, vs control. $\not \neq p<0.05$, vs diabetic group. $\sim p<0.05$, vs diabetic nephropathy group.

Renal functions in the same table shows the mean values of serum urea, serum creatinine and creatinine clearance in the diabetic group. They were insignificant compared to the corresponding values in non-diabetic control group $(25.63 \pm 1.55$ $0.74 \pm 0.06 \mathrm{mg} / \mathrm{dl}$ and $0.78 \pm 0.13 \mathrm{ml} /$ minute vs $22.38 \pm$ $1.02,0.64 \pm 0.04 \mathrm{mg} / \mathrm{dl}$ and $1.06 \pm 0.21 \mathrm{ml} /$ minute respectively). In microalb-DN group they were $(46.75 \pm 4.82,1.81 \pm 0.05 \mathrm{mg} / \mathrm{dl} \& 0.14 \pm 0.02 \mathrm{ml} /$ minute respectively) which were significant when compared to the corresponding values in diabetic group $(25.63 \pm 1.55,0.74 \pm 0.06 \mathrm{mg} / \mathrm{dl}$ and $0.78 \pm 0.13$ $\mathrm{ml} /$ minute respectively). In macroalb-DN group

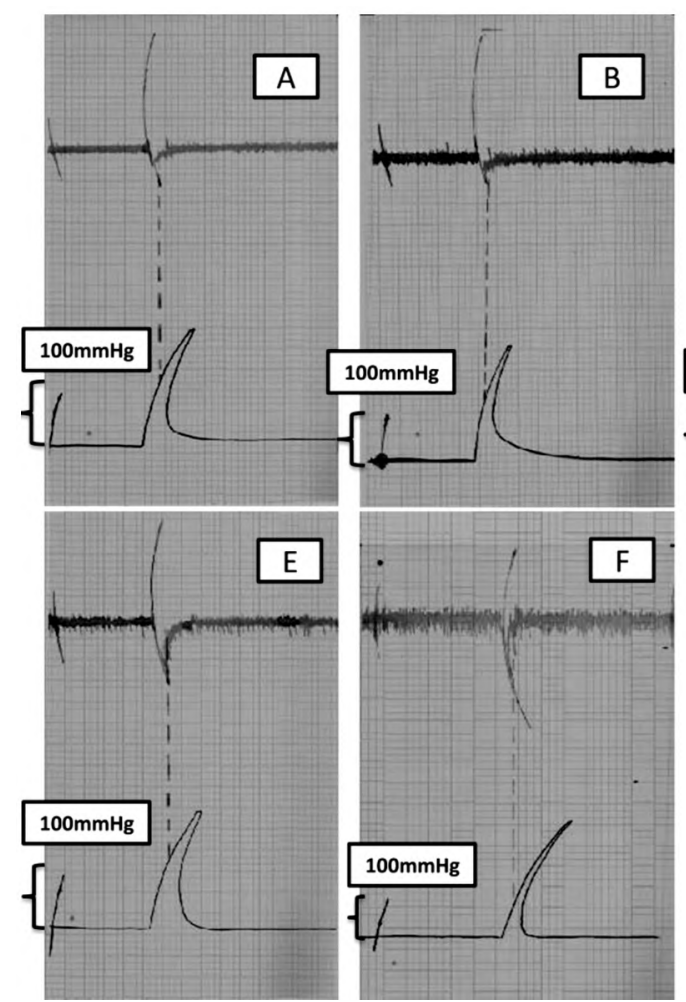

they were $(58.5 \pm 4.89,3.21 \pm 0.17 \mathrm{mg} / \mathrm{dl} \& 0.06 \pm 0.01$ $\mathrm{ml} /$ minute respectively) which were significant when compared to the corresponding values in diabetic group. In microalb-DN insulin-treated group they were $(29.50 \pm 3.55,1.43 \pm 0.12 \mathrm{mg} / \mathrm{dl} \&$ $0.5 \pm 0.15 \mathrm{ml} /$ minute respectively) which were significant when compared to corresponding values in diabetic and DN groups. In macroalb-DN insulintreated group they were $(32.63 \pm 1.77,1.78 \pm 0.12$ $\mathrm{mg} / \mathrm{dl} \& 0.43 \pm 0.05 \mathrm{ml} /$ minute respectively) which were significant when compared to corresponding values in diabetic and DN groups.

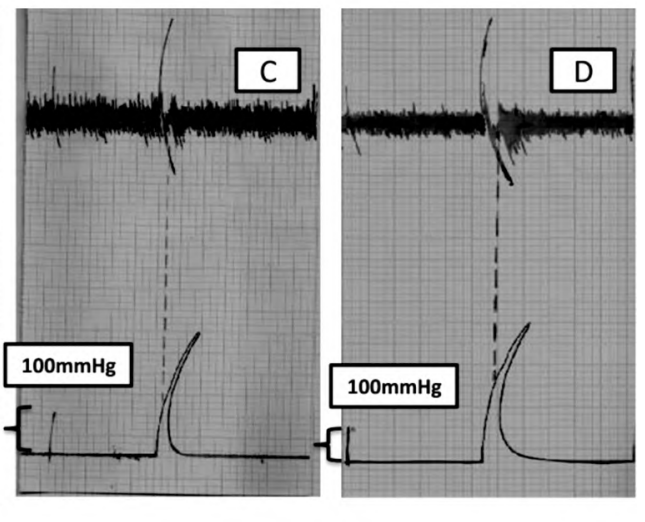
A: Non diabetic control group.
B: Diabetic non-treated group.
C: Microalb. DN group.
D: Microalb. DN group.
E: Microalb. insulin treated DN group.
F: Macroalb. insulin treated DN group.

Fig. (1): Rat tail systolic blood pressure $(\mathrm{mmHg})$ in all tested groups. 
Fig. (1) shows the SBP in all tested groups. In diabetic group it was insignificant (133.75 \pm 5.73 vs $108.38 \pm 2.95 \mathrm{mmHg}$ respectively) when compared to the corresponding value in nondiabetic control group. In microalb-DN and macroalb-DN groups it was $(195 \pm 29.98 \& 270 \pm$ $17.32 \mathrm{mmHg}$ respectively) which were signifi- cantly higher when compared to the corresponding value in diabetic group $(133.75 \pm 5.73 \mathrm{mmHg})$. In microalb-DN and macroalb-DN insulin-treated groups they were $145.25 \pm 4.98 \& 179.75 \pm 18.31$ $\mathrm{mmHg}$ respectively) which were significantly lower when compared to corresponding values in DN groups.

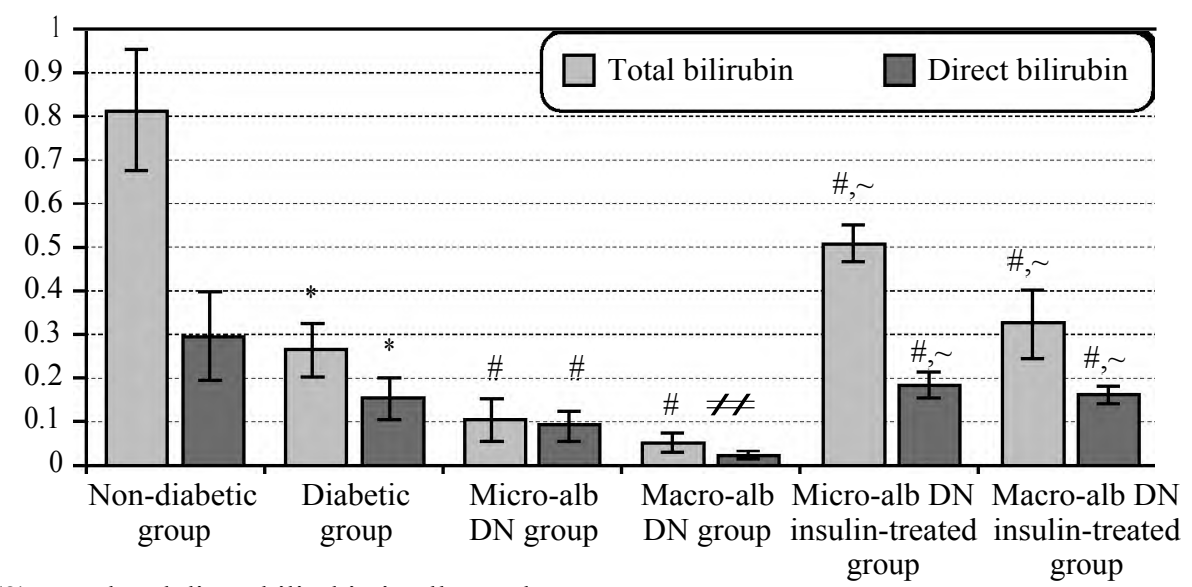

Fig. (2): Total and direct bilirubin in all tested groups: Data are expressed as mean \pm S.E.M. $(n=10)$. One way ANOVA: $* p<0.05$, vs control. $\quad \# p<0.05$, vs diabetic group. $\quad \sim p<0.05$, vs diabetic nephropathy group.

Fig. (2) shows the total and direct bilirubin in all tested groups, as the figure shows they were $(0.26 \pm 0.06 \& 0.15 \pm 0.05 \mathrm{mg} / \mathrm{dl}$ respectively $)$ in the diabetic group, which were significantly lower than corresponding values in non-diabetic control group $(0.8 \pm 0.14 \& 0.29 \pm 0.1 \mathrm{mg} / \mathrm{dl}$ respectively $)$. The mean values of serum total and direct bilirubin in microalb-DN group were $(0.1 \pm 0.05 \& 0.09 \pm 0.03 \mathrm{mg} / \mathrm{dl}$ respectively) which were significantly lower than corresponding values in diabetic group. In macroalb$\mathrm{DN}$ group they were $(0.05 \pm 0.02 \& 0.02 \pm 0.01 \mathrm{mg} / \mathrm{dl}$ respectively) which were significantly lower than corresponding values in diabetic group. The mean values of serum total and direct bilirubin in microalb-DN insulin treated group were $(0.5 \pm 0.04 \&$ $0.18 \pm 0.03 \mathrm{mg} / \mathrm{dl}$ respectively) which were significantly higher than corresponding values in diabetic and $\mathrm{DN}$ groups. The mean values of serum total and direct bilirubin in macroalb-DN insulin-treated group were $(0.32 \pm 0.08 \& 0.16 \pm 0.02 \mathrm{mg} / \mathrm{dl}$ respectively) which were significantly higher than the corresponding values in diabetic and $\mathrm{DN}$ groups.

Table (2): Correlation between total and direct billirubin and the level of micro albuminuria and macroalbuminuria.

\begin{tabular}{llc}
\hline & \multicolumn{2}{c}{ Total } \\
billirubin & $\begin{array}{c}\text { Direct } \\
\text { billirubin }\end{array}$ \\
\hline Microalbuminuria in DN group & $-0.720^{*}$ & -0.155 \\
Macroalbuminuria in DN group & $-0.934^{*}$ & -0.185 \\
Microalbuminuria in insulin treated DN group & $0.573 *$ & 0.527 \\
Macroalbuminuria in insulin treated DN group & $0.871 *$ & 0.674 \\
\hline * & &
\end{tabular}

*Significant correlation.
Table (2) shows that there was significant negative correlation between total bilirubin and the level of both micro and macroalbuminuria in DN group and significant positive correlation between total bilirubin and the level of both micro and macroalbuminuria in insulin-treated DN group. Direct bilirubin had insignificant correlation with both micro and macroalbuminuria in both groups.

Table (3): Correlation between total and direct billirubin and all tested parameter.

\begin{tabular}{|c|c|c|c|c|}
\hline & \multicolumn{2}{|c|}{ Total billirubin } & \multicolumn{2}{|c|}{ Direct billirubin } \\
\hline Fasting serum glucose & & $-0.342 *$ & & -0.223 \\
\hline $\mathrm{HbA1} \mathrm{c}$ & & $-0.211^{*}$ & & -0.082 \\
\hline ALT & & $-0.165^{*}$ & & -0.130 \\
\hline AST & & $0.045^{*}$ & & -0.024 \\
\hline ALP & & 0.111 & & -0.088 \\
\hline Serum albumin & & $0.030 *$ & & $0.296^{*}$ \\
\hline Bilirubin & Dirct & $0.623 *$ & Total & $0.623 *$ \\
\hline Serum urea & & $-0.097^{*}$ & & -0.176 \\
\hline Serum creatinine & & $-0.224 *$ & & -0.212 \\
\hline Creatinine clearance & & $0.161 *$ & & 0.229 \\
\hline SBP & & $-0.392 *$ & & -0.313 \\
\hline
\end{tabular}

*Significant correlation.

Table (3) illustrates the correlation between total and direct bilirubin with all tested parameter. As the table shows, there was significant negative correlation between total bilirubin and glycemic state (fasting serum glucose \& $\mathrm{HbA} 1 \mathrm{c}$ ), liver functions (ALT \& AST), renal functions (serum urea $\&$ serum creatinine), SBP, while there was significant positive correlation between total billirubin 
and serum albumin, creatinine clearance and direct billirubin, while total billirubin showed insignificant positive correlation with ALP. Also, there was insignificant positive correlation between direct billirubin and creatinine clearance \& serum albumin. While, there was insignificant negative correlation between direct billirubin and the remaining parameters.
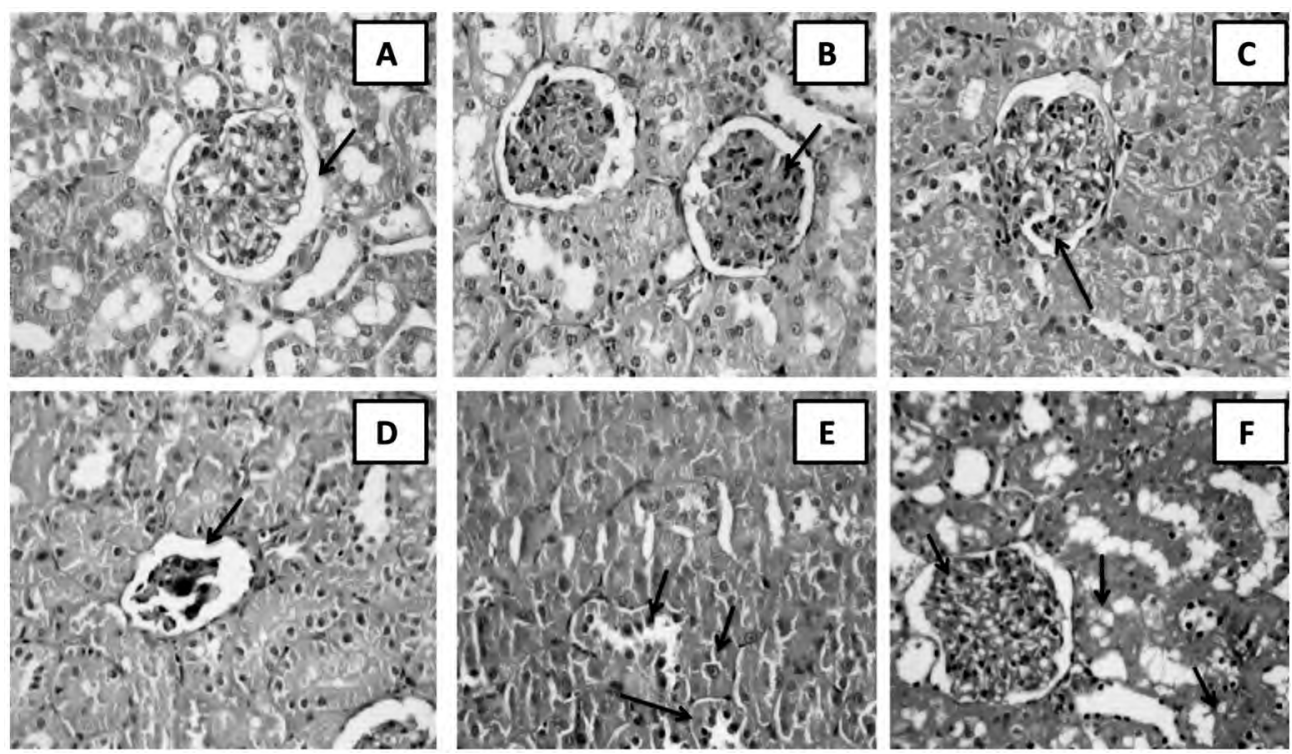

Sections of the kidney in all groups stained by hematoxylin \& eosin (x400).

A: Non diabetic control group.

B: Diabetic non-treated group.

C: Microalb. DN group.

D: Microalb. DN group.

E: Microalb. insulin treated DN group.

$\mathrm{F}$ : Macroalb. insulin treated DN group.

Fig. (3): Histopathological examination of the kidney by (H\&E x 400).

Fig. (3) shows sections of the kidney tissue stained by H\&E. It shows normal glomeruli (arrow) and tubules in non-diabetic control group (A). Slight thickening of the basement membrane of glomeruli (arrow) in diabetic group (B). Glomeruli appear healthy with very few encroaching of inflammatory cells (neutrophils) arrow with marked hydropic changes of tubules in microalbuminuric diabetic nephropathy group (C).
Marked reduced glomerular size (arrow) and hydropic changes in the tubule in macroalbuminuric diabetic nephropthy group (D). Still prominent hydropic changes in the affected tubules (arrow) in microalbuminuric insulin treated diabetic nephropathy group (E). The glomeruli appear normal but surrounded by tubules show hydropic changes in macroalbuminuric insulin treated diabetic nephropthy group $(\mathrm{F})$.
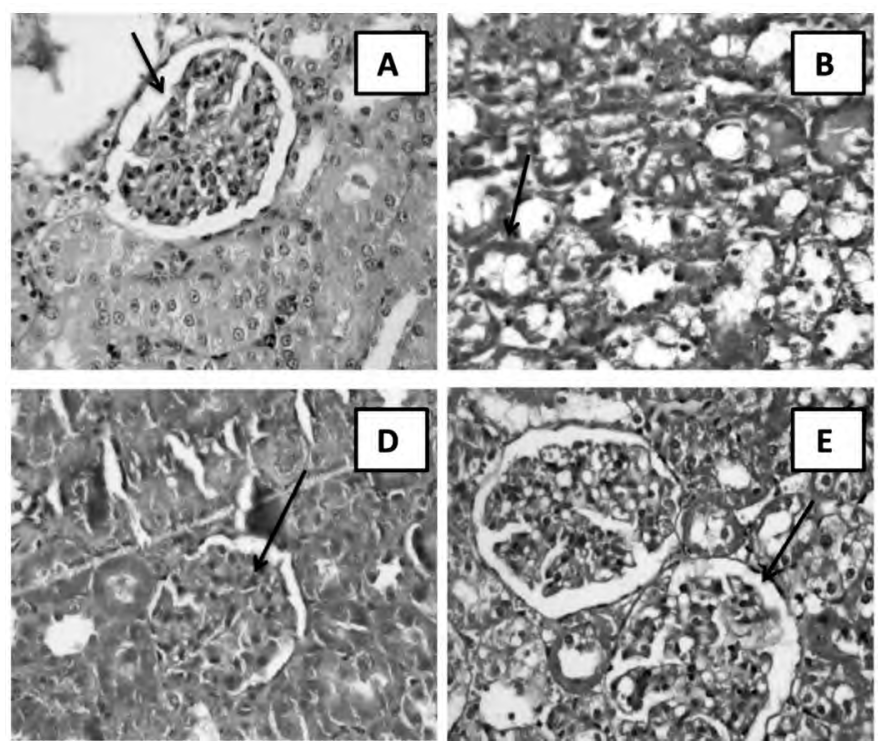

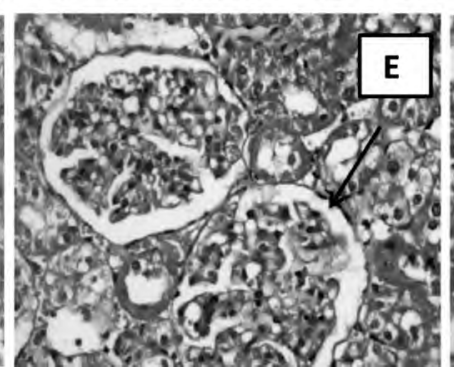

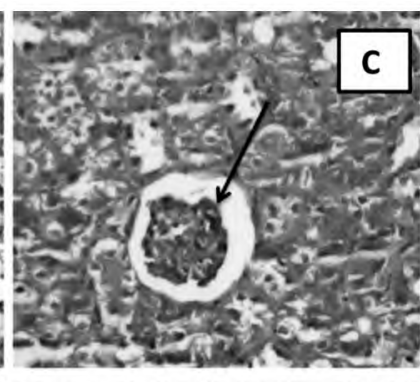

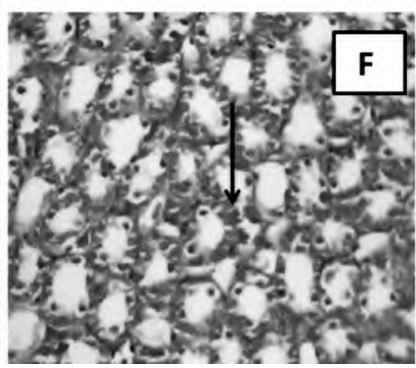

Sections of the kidney in all groups stained by PAS (Periodic acid-Schiff) stain $(x 400)$.

A: Non diabetic control group.

B: Diabetic non-treated group.

C: Microalb. DN group.

D: Microalb. DN group.

E: Microalb. insulin treated DN group.

$\mathrm{F}$ : Macroalb. insulin treated DN group.

Fig. (4): Histopathological examination of the kidney by (PASx400). 
Fig. (4) shows sections of the kidney tissue stained by PAS stain. It shows normal glomeruli (arrow) in non-diabetic control group (A). Slight hydropic changes in the affected tubule (arrow) in diabetic group (B). Slight reduced glomerular size (arrow) in microalbuminuric diabetic nephropathy group (C). Slight thickening in the glomerular basement membrane in macroalbuminuric diabetic nephropathy group (D). Normal glomeruli (arrow) in microalbuminuric insulin-treated diabetic nephropathy group (E). Tubules with slight hydropic changes in macroalbuminuric insulin treated diabetic nephropthy group $(\mathrm{F})$.

\section{Discussion}

Diabetic nephropathy is a major complication in longstanding cases of diabetes. Follow-up of diabetic patients is very important to prevent this complication. The presence of a marker to monitor the progression of the disease is of great value, especially if this marker is an endogenously secreted substance.

Our study showed that both total and direct bilirubin, were significantly lower in diabetic group when compared to the corresponding values in non-diabetic group. Also, they were significantly lower in diabetic nephropathy group when compared to the corresponding values in diabetic group and were significantly lower in macroalbDN group when compared to the corresponding values in microalb DN group. This means that bilirubin levels significantly decreased with the progression of the severity of diabetic nephropathy. The severity can be determined by significant elevation of serum glucose, $\mathrm{HbA} 1 \mathrm{C}$ and oxidative stress marker. Kidney affection in diabetic rats was determined by significant elevation of systolic blood pressure, serum urea and serum creatinin.

Total bilirubin significantly had a negative correlation with fasting serum glucose, HbA1C, ALT, AST, serum urea, serum creatinine and systolic blood pressure. There was a significant negative correlation between total bilirubin and both the microalbuminuria and macroalbuminuria in diabetic nephropathy groups but direct billirubin showed insignificant negative correlation with both of them.

Bilirubin was regarded as a toxic end product that must be excreted from the body. However Stocker [23], said that bilirubin is a strong antioxidant that can scavenge oxidants even more powerful than alpha-tocopherol. It has a powerful antiinflammatory and antioxidant effects as it can inhibit oxidant generation by inhibiting $\mathrm{NAD}(\mathrm{P}) \mathrm{H}$ oxidase pathway and protein kinase C. It has been regarded as the most effective endogenous antioxidant of lipid peroxidation.

In our study, there was elevation of serum glucose, $\mathrm{HbA} 1 \mathrm{C}$ in diabetic and diabetic nephropathy groups compared with control group. This was concomitant with significant decrease in total and direct bilirubin in diabetic and diabetic nephropathy groups. Previous studies reported negative association between serum bilirubin and glucose tolerance test. This means that decrease serum bilirubin is a risk factor in the development of diabetes and its complications [24].

In diabetic nephropathy group, both serum ALT and AST were significantly higher when compared to the corresponding values in diabetic and control groups. These results were in agreement with Lebovitz [25], who found that serum ALT, AST were 1-2.5 times higher than the upper normal in diabetes. According to Neuschwander [26] and Harris [27], individuals with type 2 diabetes have a higher incidence of liver function test abnormalities than non-diabetics.

Also, the systolic blood pressure was significantly increased in diabetic nephropathy group compared with corresponding values in control and diabetic groups. In accordance with our results Inoguchi [28] reported that the prevalence of vascular complications in diabetic patients with Gilbert syndrome, a congenital hyperbilirubinemia, is lower compared to those without this syndrome. On the other hand individuals with low bilirubin level are highly exposed to coronary atherosclerosis [29]. Also, several literatures have reported the association between diabetic microvascular complications such as neuropathy, nephropathy and retinopathy with low bilirubin $[\mathbf{3 0 , 3 1}]$

Our data revealed significant elevation of serum urea, creatinine and significant decrease in creatinine clearance in diabetic nephropathy group compared with corresponding values in control and diabetic groups. In diabetic patients, higher serum bilirubin levels were associated with a lower risk of progression of albuminuria even with poorer glycemic control [32]. Also, Fukui [33] discovered a significant negative correlation between serum bilirubin levels and urinary albumin excretion in diabetic patients and concluded that lower serum bilirubin levels were associated with a higher prevalence of microalbuminuria. Hyperglycemia in the diabetic range can cause microalbuminuria by glucose-related mechanism. Glucose causes glycation of basement membrane proteins with 
loss of charge selectivity and glomerular hyperperfusion and hyperfiltration [34]. Also, Riphagen [35] found a negative correlation between baseline serum bilirubin levels and the doubling of serum creatinine levels and end-stage renal disease.

Our data revealed significant negative correlation between serum bilirubin and the progression of DN. This can be explained by previous studies which demonstrate a negative correlation between bilirubin levels and oxidative stress markers. Ha \& Lee [36], reported that oxidative stress has been shown to play an important role in the development and progression of diabetic nephropathy as reactive oxygen species mimic the stimulatory effects of high glucose and up regulate TGF- $\beta 1$, plasminogen activator-1 and extracellular matrix proteins by glomerular mesangial cells, thus leading to mesangial expansion. Moreover, oxidative stress was associated with the development of diabetic microvascular complications [37]. Fujii [38] reported that hyperbilirubinemia and the administration of biliverdin, which is converted rapidly to bilirubin by biliverdin reductase, protected mice against diabetic nephropathy via inhibition of oxidative stress. These results indicate that bilirubin acts as a radical scavenger and can inhibit oxidative stress.

On histopathological examination of kidney tissues in diabetic group by H\&E and PAS stains revealed slight thickening of the basement membrane, slight thickening of the arterioles with few inflammatory cells in the interstitium and slight hydropic changes in the tubule. In the microalbuminuric diabetic nephropathy group histopathological examination showed slight hydropic changes in the affected tubules with few encroaching of inflammatory cells (neutrophils) in the glomeruli by $\mathrm{H} \& \mathrm{E}$ stain and slight reduced glomerular size by PAS stain. All these changes were insignificant when compared to the corresponding values in diabetic group. In macroalbuminuric diabetic nephropathy group histopathological examination by H\&E stain showed prominent hydropic changes in the renal tubules with cast formation, marked reduced glomerular capillary size, increase in the mesangial matrix, collection of chronic inflammatory cells mainly lymphocytes and focal fatty metaplasia in the interstitium. PAS stain showed thickening of the glomerular basement membrane, hyaline cast formation in the lumen of the tubules and multifocal mesengial matrix expansion in the affected glomeruli. All these changes were significant when compared to diabetic group.

These results were consistent with Kashihara [39], who postulated that renal dysfunction in dia- betic kidney was caused by the alterations in the structure of the kidney, detected by glomerular basement membrane thickening, mesangial cell matrix deposition, and the effacement of podocyte foot processes. Also, renal damage correlated with the degree of tubule-interstitial fibrosis which is the final manifestation of end stage renal disease [40]. Chow [41], suggested that the progressive injury and fibrosis in diabetic nephropathy was associated with accumulation of macrophages in diabetic kidney mice correlated with the degree of renal injury and fibrosis.

In insulin-treated diabetic nephropathy group, both total and direct bilirubin in this group was significantly higher when compared to diabetic and diabetic nephropathy non-treated groups in the present investigation. This can be explained by the fact that insulin treatment decreased blood glucose levels and improved oxidative stress with concomitant elevation of billirubin levels as antioxidant. Jain [42] and Gao [43], reported that uncontrolled DM is associated with significant increase in the oxidative stress and inflammatory conditions and insulin treatment decreased oxidative stress.

Insulin does not possess a direct antioxidant action [44] . Therefore, the suppressive action of insulin in the diabetic rats may be secondary action due to its hypoglycemic effect. The overall glycemic control afforded by insulin treatment is effective enough to prevent excessive protein glycation which can increase tissue oxidative stress. It is clear that, in diabetic tissue, the effects of different agents on oxidative stress depend largely on how they alter the balance between production and destruction of ROS [45].

Histopathological changes of insulin-treated diabetic nephropathy group (microalb \& macroalb) by H\&E stain and PAS stain showed some healthy glomeruli, but still hydropic changes in the affected tubules. All these changes were insignificant when compared to non-treated groups. In our study treatment with insulin alone didn't reverse all the histopathological changes. These findings were consistent with that of Fioretto [46], who stated that glycaemia cannot be controlled to the degree necessary to reverse histopathological changes in DN. Although the above findings were contradicted with Schmitz, [47] who stated that intensified insulin treatment and good metabolic control bring the GFR towards normal levels after a period of weeks to months in both IDDM and NIDDM with regression of both glomerular hyperfiltration and renal hypertrophy. 


\section{References}

1- NJØLSTAD P.R., et al.: Permanent neonatal diabetes caused by glucokinase deficiency: Inborn error of the glucose-insulin signaling pathway. Diabetes, 52 (11): p. 2854-60, 2003.

2- TAKAYANAGI R., INOGUCHI T. and OHNAKA K.: Clinical and experimental evidence for oxidative stress as an exacerbating factor of diabetes mellitus. Journal of Clinical Biochemistry and Nutrition, 48 (1): p. 72-77, 2010.

3- PEERAPATDIT T. and SRIRATANASATHAVORN C.: Lipid peroxidation and antioxidant enzyme activities in erythrocytes of type 2 diabetic patients. J. Med. Assoc. Thai., 93 (6): p. 682-693, 2010.

4- BROWNLEE M.: Biochemistry and molecular cell biology of diabetic complications. Nature, 414 (6865): p. 813, 2001.

5- THOMSON S.E., et al.: Renal connective tissue growth factor correlates with glomerular basement membrane thickness and prospective albuminuria in a non-human primate model of diabetes: Possible predictive marker for incipient diabetic nephropathy. Journal of Diabetes and its Complications, 22 (4): p. 284-294, 2008.

6- MAZZONE G.L., et al.: Bilirubin inhibits the TNF arelated induction of three endothelial adhesion molecules. Biochemical and biophysical research communications, 386 (2): p. 338-344, 2009.

7- KIM E.S., et al.: Inverse association between serum bilirubin levels and arterial stiffness in Korean women with type 2 diabetes. PloS One, 9 (10): p. e109251, 2014.

8- KUMAR A., et al.: Oxidative stress in neonatal hyperbilirubinemia. Journal of tropical pediatrics, 53 (1): p. 69 $71,2006$.

9- HOWARTH F., et al., Long-term effects of streptozotocininduced diabetes on the electrocardiogram, physical activity and body temperature in rats. Experimental physiology, 90 (6): p. 827-835, 2005.

10- BEKЮNAR S., GÜRDÖL F. and SEFEROG LU G.: A study on the relationship between homocysteine and diabetic nephropathy in rats. Pharmacological Research, 45 (3): p. 249-252, 2002.

11- KUHAD A. and CHOPRAK.: Tocotrienol attenuates oxidative-nitrosative stress and inflammatory cascade in experimental model of diabetic neuropathy. Neuropharmacology, 57 (4): p. 456-462, 2009.

12- GROSS J.L., et al.: Diabetic nephropathy: Diagnosis, prevention, and treatment. Diabetes Care, 28 (1): p. $164-$ 176, 2005.

13- WANG C., CHAO L. and CHAO J.: Direct gene delivery of human tissue kallikrein reduces blood pressure in spontaneously hypertensive rats. The Journal of clinical investigation, 95 (4): p. 1710-1716, 1995.

14- SCHERMER S.: Rats Haemopietic system in: Blood morphology of laboratory animals. Chap. 10. $\mathrm{Pb} 1$. Davis. FA Co., Philadelphia, p. 112, 1968.

15- KOENIG R.J., et al.: Correlation of glucose regulation and hemoglobin AIc in diabetes mellitus. New England Journal of Medicine, 295 (8): p. 417-420, 1976.
16- SABBATINI M., et al.: Effect of calcium antagonists on glomerular arterioles in spontaneously hypertensive rats. Hypertension, 35 (3): p. 775-79, 2000.

17- ANTAI A.B., et al.: Serum protein and enzyme levels in rats following administration of ethanolic leaf extract of Ageratum conyzoides (goat weed). Nigerian Journal of Physiological Sciences, 24 (2), 2009.

18- WEBSTER D., BIGNELL A.H.C. and ATTWOOD E.C.: An assessment of the suitability of bromocresol green for the determination of serum albumin. Clinica Chimica Acta, 53 (1): p. 101-8, 1974.

19- MACNEIL M.L., et al.: Considerations when measuring urinary albumin: precision, substances that may interfere, and conditions for sample storage. Clinical chemistry, 37 (12): p. 2120-23, 1991

20- PATTON C.J. and CROUCH S.R.: Spectrophotometric and kinetics investigation of the Berthelot reaction for the determination of ammonia. Analytical Chemistry, 49 (3): p. 464-9, 1977.

21- SCHLATZER D., et al.: Novel urinary protein biomarkers predicting the development of microalbuminuria and renal function decline in type 1 diabetes. Diabetes Care, p. DC_111491, 2012.

22- SIBILIA V., et al.: Ghrelin protects against ethanol-induced gastric ulcers in rats: Studies on the mechanisms of action. Endocrinology, 144 (1): p. 353-9, 2003.

23- STOCKER R., et al.: Bilirubin is an antioxidant of possible physiological importance. Science, 235 (4792): p. 1043 46, 1987.

24- KO G.T.C., et al.: Serum bilirubin and cardiovascular risk factors in a Chinese population. Journal of cardiovascular risk, 3 (5): p. 459-463, 1996.

25- LEBOVITZ, H.E., KREIDER M. and FREED M.I.: Evaluation of liver function in type 2 diabetic patients during clinical trials: Evidence that rosiglitazone does not cause hepatic dysfunction. Diabetes Care, 25(5): p. 815-21, 2002.

26- NEUSCHWANDERÂaTETRI B.A. and CALDWELL S.H.: Nonalcoholic steatohepatitis: summary of an AASLD Single Topic Conference. Hepatology, 37 (5): p. 1202 19, 2003.

27- HARRIS E.H.: Elevated liver function tests in type 2 diabetes. Clinical Diabetes, 23 (3): p. 115-19, 2005.

28- INOGUCHI T., et al.: Relationship between Gilbert syndrome and prevalence of vascular complications in patients with diabetes. Jama, 298 (12): p. 1396-1400, 2007.

29- LIN J.-P., VITEK L. and SCHWERTNER H.A.: Serum bilirubin and genes controlling bilirubin concentrations as biomarkers for cardiovascular disease. Clinical Chemistry, 56 (10): p. 1535-43, 2010.

30- KIM E.S., et al.: Inverse association between serum total bilirubin levels and diabetic peripheral neuropathy in patients with type 2 diabetes. Endocrine, 50 (2): p. 405$412,2015$.

31- SEKIOKA R., et al.: Serum total bilirubin concentration is negatively associated with increasing severity of retinopathy in patients with type 2 diabetes mellitus. Journal of Diabetes and its Complications, 29 (2): p. 218-221, 2015. 
32- SEDEEK M., et al.: Critical role of Nox4-based NADPH oxidase in glucose-induced oxidative stress in the kidneyimplications in type 2 diabetic nephropathy. American Journal of Physiology-Heart and Circulatory Physiology, 2010 .

33- FUKUI M., et al.: Relationship between serum bilirubin and albuminuria in patients with type 2 diabetes. Kidney international, 74 (9): p. 1197-1201, 2008.

34- FUJITA H., NARITA T. and ITO S.: Abnormality in urinary protein excretion in Japanese men with impaired glucose tolerance. Diabetes Care, 22 (5): p. 823-6, 1999.

35- RIPHAGEN I.J., DEETMAN P.E. and BAKKER S.J.: Bilirubin and protection against progression of diabetic nephropathy. Proceedings of the Kidney Week, 2012.

36- HA H. and LEE H.B.: Reactive oxygen species and matrix remodeling in diabetic kidney. Journal of the American Society of Nephrology, 14 (Suppl 3): p. S246-S9, 2003.

37- MADSEN-BOUTERSE S.A. and KOWLURU R.A.; Oxidative stress and diabetic retinopathy: Pathophysiological mechanisms and treatment perspectives. Reviews in Endocrine and Metabolic Disorders, 9 (4): p. 315-27, 2008.

38- FUJII M., et al.: Bilirubin and biliverdin protect rodents against diabetic nephropathy by downregulating NAD (P) H oxidase. Kidney international, 78 (9): p. 905-19, 2010.

39- KASHIHARA N., et al.: Oxidative stress in diabetic nephropathy. Current medicinal chemistry, 17 (34): p. 4256-69, 2010.
40- ZEISBERG M., STRUTZ F. and G.A. M ${ }^{1} / 4$ LLER: Role of fibroblast activation in inducing interstitial fibrosis. Journal of Nephrology, 13: p. S 111-20, 2000.

41- CHOW F.Y., et al.: Macrophages in streptozotocin-induced diabetic nephropathy: potential role in renal fibrosis. Nephrology Dialysis Transplantation, 19 (12): p. $2987-$ 96, 2004.

42- JAIN D., et al.: Protective effect of diosmin against diabetic neuropathy in experimental rats. J. Integr. Med, 12 (1): p. 35-41, 2014

43- GAO Y., et al.: Radix Astragali lowers kidney oxidative stress in diabetic rats treated with insulin. Endocrine, 42 (3): p. 592-8, 2012

44- YOSHIDA M., et al.: Effect of combined vitamin E and insulin administration on renal damage in diabetic rats fed a high cholesterol diet. Biological and Pharmaceutical Bulletin, 28 (11): p. 2080-6, 2005.

45- ZOBALI F., et al.: Effects of vitamin A and insulin on the antioxidative state of diabetic rat heart: A comparison study with combination treatment. Cell Biochemistry and Function, 20 (2): p. 75-80, 2002.

46- FIORETTO P., et al.: Reversal of lesions of diabetic nephropathy after pancreas transplantation. New England Journal of Medicine, 339 (2): p. 69-75, 1998.

47- SCHMITZ A., CHRISTENSEN T. and JENSENT F.T. Glomerular filtration rate and kidney volume in normoalbuminuric non-insulin-dependent diabetics-lack of glomerular hyperfiltration and renal hypertrophy in uncomplicated NIDDM. Scandinavian journal of clinical and laboratory investigation, 49 (2): p. 103-8, 1989. 


\section{مستوى البيلوروبين فى السيرم يمكن استخدلامه كملامة بيولوجية فى تطور اعتلال

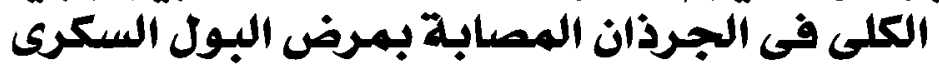

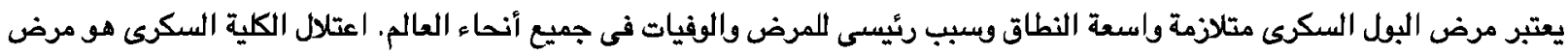

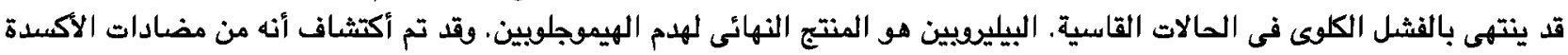

الهدف من البحث: فى هذا العمل، ندرس التغيرات فى مستوى البيليروبين فى مصل الدم في حالات اعثلال الكلية السكرى ومعرفة ما إذا

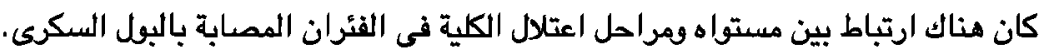

مواد وطرق البحث: تم استخدام ستين ذكر من الفئران البيضاء وقد قسمت إلى المجموعات التالية المجموعة الضابطة، مجموعة اعتلال

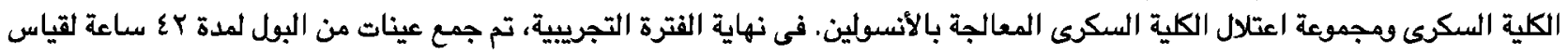

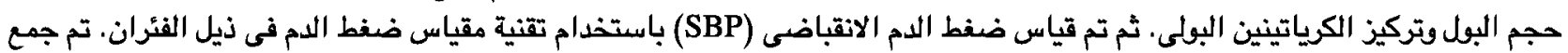

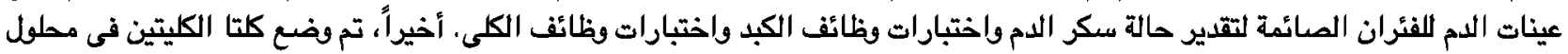

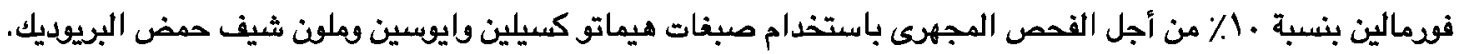

النتائج: أظهرت النتائج أن حقن الفئران بالستربتونوتوسين ادت إلى ارتفاع فى سكر الدم، وانزيمات وظائف الكبد وانزيمات وظائف الكية الكية،

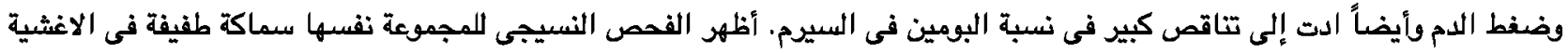

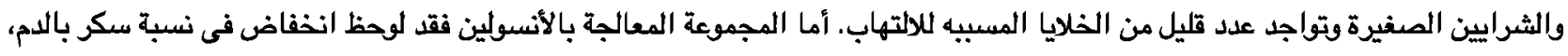

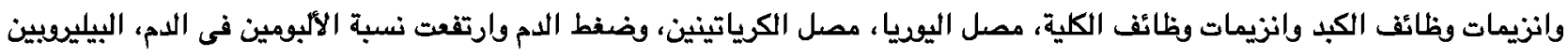

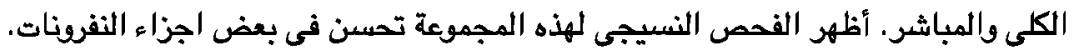

الخلاصة: المتابعة المنتظمة اللييليرويين فى مرضى البول السكرى هى علامة أساسية اللقدم المرض ومتابعة التشخيصى وتأثير العلاج

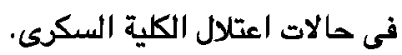

